DISASTER MEDIA

\title{
Atomic Histories and Elemental Futures across Indigenous Waters
}

Hi'ilei Julia Hobart ${ }^{a}$

Keywords: elements, anthropocene, climate change, indigenous politics, cold war

https://doi.org/10.1525/001c.21536

Kathy Jetñil-Kijiner and Aka Niviâna's 2018 collaborative video poem Rise is a trans-Indigenous call to action. Set along the watery edges of the Republic of the Marshall Islands and the stark ice sheets of Greenland, the images that accompany their words train our eyes on water: a common, critical element of life as it shapeshifts across the globe. As climate change threatens the homeland of each poet through rapidly increasing glacial melt, the poem articulates how the Western world's willful denial of irreversible damage performs a colonial violence with deep roots. This article contextualizes $R$ ise by exploring nuclear histories of dispossession used to make way for the extension of normative American domestic life onto and into Indigenous territories cleared for Cold War projects. In doing so, I consider how Jetñil-Kijiner and Niviâna offer a particularly salient response to the militarized infrastructures so violently imposed upon their territories in order to trouble the spatial and conceptual cleaving of anthropogenic precarity between "remote" places and a culpable Western world.

\section{A Mirror, a Bellwether}

\author{
Sister of ice and snow \\ I'm coming to you \\ from the land of my ancestors, \\ from atolls, sunken volcanoes-undersea descent \\ of sleeping giants
}

Sister of ocean and sand

I welcome you

to the land of my ancestors

— to the land where they sacrificed their lives

to make mine possible

- to the land

of survivors.

\footnotetext{
a Hi'ilei Julia Kawehipuaakahaopulani Hobart is Assistant Professor of Anthropology at the University of Texas at Austin. She holds a PhD in Food Studies from New York University, an MA in Studies in the Decorative Arts, Design, and Culture from the Bard Graduate Center and an MLS in Archives Management and Rare Books from the Pratt Institute. Her research and teaching is broadly concerned with Indigenous foodways, Pacific Island studies, settler colonialism, urban infrastructure, and the performance of taste. Her book on the social history of comestible ice in Hawai i i, forthcoming from Duke University Press, investigates the sensorial and affective dimensions of Native dispossession. In particular, she is interested in how personal and political investments in coldness facilitate ideas about race, belonging, comfort, and leisure in the Pacific.
} 
Poets Kathy Jetñil-Kijiner and Aka Niviâna greet each other in their 2018 collaborative video poem Rise: From One Island to Another by calling upon the elements of their homes - ice, snow, ocean, sand - as both an introduction and an explanation of how they are related to each other as people of islands and waters (Jetñil-Kijiner and Niviâna 2019). These opening stanzas are accompanied by images of Jetñil-Kijiner in the Republic of the Marshall Islands (RMI) and Niviâna in Greenland, the places that they are of, and as they traverse these spaces, the viewer glimpses the effects of climate change upon their homelands. Three successive frames show Jetñil-Kijiner at the shoreline, then knee-deep, then neck-deep in ocean, as she faces the camera with pursed lips and steady eyes. If Jetñil-Kijiner sinks underwater, then Niviâna rises as she hikes up a glacial slope, ice crunching under her boots, until she stands atop a cliff where a lavender-colored flower blooms out of stone. Expansive shots of glacial landscapes reference the accelerated melt that causes islands on opposite sides of the globe to sink and recede:

Let me show you the tide

that comes faster

than we'd like to admit

Jetñil-Kijiner says.

Can you see our glaciers groaning

with the weight of the world's heat?

Niviâna replies.

In orienting themselves to one another, and their audience to these islands, the artists ask us to bear witness to sinking, shifting, and melting worlds. And as they do, they remind viewers that they, too, inherit futures rendered precarious in the age of the Anthropocene. The poets belong to a genealogy of Indigenous scholars, artists, and activists who identify climate change as a product of historical and ongoing colonial violence, produced through the paradigms of dispossession, nuclearization, and racial capitalism (Hogue and Maurer 2020). In examining what the Anthropocene offers as a term and an analytic, Zoe Todd and Heather Davis argue for the temporal parameters of this epoch to be aligned with the beginning of colonialism in order to account for how unequal power relations, histories of extraction, and racism have produced the current global environmental condition (Davis and Todd 2017). Moves by Indigenous scholars to counter the apolitical assignation of climate change (as one that tends only to identify victims, while avoiding blame) have been central to theorizing the Anthropocene with place-based and cultural specificity (Suliman et al. 2019; TallBear 2017). As Kyle Powys Whyte explains, Indigenous people are well positioned for this kind of critique because they engage deep histories of ecological knowledge with well-honed 


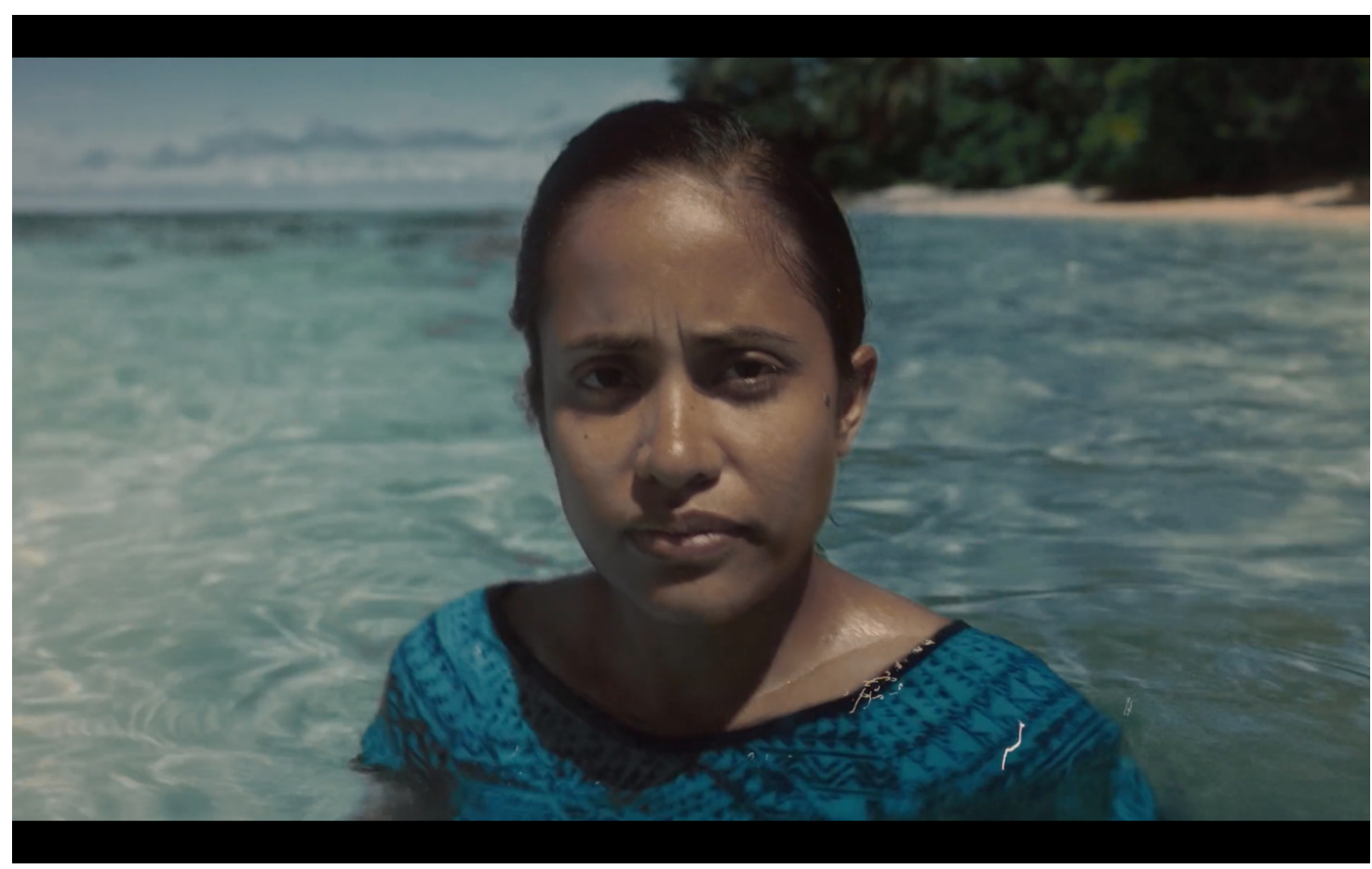

Figure 1: Rise: From One Island to Another (Jetñil-Kijiner and Niviâna 2019).

Source: https://350.org/rise-from-one-island-to-another/. Image courtesy of the artists.

strategies of adaptability. To be Indigenous in the age of the Anthropocene, then, is to know a pervasive reality for which new relations must be forged in order to survive displacements mobilized by global warming. "Indigenous imaginations of our futures in relation to climate change-stuff of didactic science fiction-begin already with our living today in a post-apocalyptic situation," writes Whyte $(2017,160)$. Rather than a sci-fi imagining of a distant future, the postapocalypse is now: a sinking island and a disappearing glacier, and water is climate change's most devastating refugee (Lempert 2018, 203; Hobart 2020). ${ }^{1}$

Within the Western popular imagination, places like the RMI and Greenland are often used as mirrors or-perhaps more accurately-as bellwethers: an example of what could be (or what will become of) the so-called First World (Farbotko 2010). ${ }^{2}$ They are rarely made meaningful on their own. Instead, reports published in major news outlets describe a "melting" Greenland and a "disappearing" Marshall Islands by translating their loss through symbolic forms deemed more legible to the average American. For example, in an accounting of Greenland's ice melt, estimated at 280 billion tons annually between 2002 and 2016, the National Geographic explains, "this average annual ice melt is enough to cover the entire states of Florida and New York hip

\footnotetext{
1 I am careful here to refrain from calling this a dystopia, per Lempert's important warning that "dystopian ethnographic depictions may unintentionally serve to reinforce the dispossession of Indigenous futures” (2018, par. 2).

2 Carol Farbotko usefully describes this phenomenon as "the cosmopolitan imaginative geographies of climate change" (2010, 47).
} 
deep in meltwater, as well as drowning Washington, D.C. and one or two other small states" (Leahy 2019). Likewise, a New York Times feature details how Marshallese and ri-Pikinni (Bikini Islanders), under the Compact of Free Association-a political agreement made in the wake of atomic obliteration-may emigrate to the United States, and so the rising sea levels that flood Micronesian homes threaten to burden American "immigration policy, national security, and taxpayer dollars" (Davenport 2015). Such equivalencies help the Western reader calculate the enormity of climate change through projected future loss, while simultaneously producing it as a problem experienced by others elsewhere.

Using Rise to look both backward and forward, from atomic histories toward the elemental futures they propose, presents an opportunity to recalibrate disaster media archives against growing demands for white investments in Indigenous futures. Here I treat the category of disaster media capaciously to include the manipulations of ongoing nuclear catastrophe in the service of imperialism (to echo the language of Rebecca Hogue and Anaiis Maurer), as well as the artistic productions that demand affective investments from settler environmentalists (Bahng 2020). Casting climate change relative to domestic American impact reveals the ways in which whiteness remains the unmarked center of apocalyptic anxiety by setting up false distinctions between drastic climate change "over there" to its pending encroachment "over here." To that end, I consider Rise in the context of Cold War mass media like photographs and newsreels, formats that Nathan Atkinson describes as "public propaganda" used to bolster citizen support of catastrophic military technologies (Atkinson 2011).

Extending arguments that nuclear photography endeavored to "take the place out of the landscape" so as to replace public concerns around ethics instead with awe, I track the movement of peoples necessary to, first, produce terra nullius - a space emptied and made available for atomic warfare-and second, to mark that space as distinctly American through the installation of miniature suburbias in the form of military bases and bunkers (Kirsch 1997, 229; Hales 1991). Social, geographical, and material practices of division-split atoms, nuclear family units-reflect what Aimee Bahng has referred to as "settler colonial... constructions of enclosure" (Bahng 2020, 48). This article thus tracks the extension of heteronormative American domestic life onto and into Indigenous territories cleared for Cold War projects: a manifest destiny for the nuclear age. The two examples that I focus on (a photo essay published in Life and a short documentary film produced by the US Department of Defense) are part of broader state-sponsored media efforts coordinated to foment American acceptance of the Cold War. After charting this mediated phenomenon, I conclude by turning to the forms of Indigenous relationality and interdependence proposed by Rise. Across this arc, from atomic histories to elemental futures, I show how a "homemaking project" that once collapsed 
the "here" and "there" of US empire now envisions a difference that overlooks American complicity in apocalyptic climate futures upon Indigenous lands across North America, Oceania, and the Arctic.

\section{Atomic Histories of Removal}

It is, in part, because of the presumed insignificance of the Marshall Islands and Greenland (and by extension their people) that these two places became pulled into the crosshairs of atomic geopolitical warfare. Rise gestures toward Cold War contexts throughout its visual narrative: at one point, the camera lingers on a rusted military tank; at another, a collection of stark white coral sits like a cairn atop the Runit Dome, a nuclear waste containment structure. These artifacts mark the histories of removal that shape contemporary Indigenous life within the long reach of American empire, in which environments and nonhuman relations negotiate contamination and toxicity's afterlives (Powell 2018; Masco 2006). ${ }^{3}$ Aligning with what Kristen Simmons terms settler atmospherics, in which "the atmosphere becomes not only a means for violence and control, but also one through which affects to demean are engineered," the deteriorating habitability of these territories was set in motion long before the ice caps began their grim retreats (Simmons 2017).

Not long after the United States gained control of the Marshall Islands in 1944, it identified the archipelago as an ideal nuclear testing ground, not least because its relatively small number of residents could be convinced to evacuate elsewhere through various forms of social and political manipulation (Teaiwa 1994, 89; Smith-Norris 2017). ${ }^{4}$ As Marshallese activist Darlene Keju-Johnson recalled, "in 1946, a U.S. Navy officer came to Bikini Island and told Chief Juda, 'We are testing these bombs for the good of mankind, and to end all wars'... the naval officer did not tell the chief that the Bikinians would never see their home again" (Keju-Johnson 2003, 309). With the understanding that they would be able to return to their homes within a few months, ri-Pikinni agreed to temporary relocation in order to make room for Operation Crossroads, the first of many nuclear testing projects that have left large areas of the Marshall Islands uninhabitable to this day (Niedenthal 1997, 28-29; Teaiwa 1994, 89). Moved to first Rongdrik (Rongerik), then Ānewetak, then Kuwajleen (Kwajalein), and then Kōle (Kili), ri-Pikinni struggled to survive as the United States tested sixty-seven nuclear bombs on Pikinni (Bikini) and other nearby sites between 1946 and 1958. ${ }^{5}$ An article published in 1946 about the "atom bomb island" in popular Life magazine uncritically reflected that

\footnotetext{
3 While this article focuses on contexts abroad, it is important to connect them to domestic American projects like the military proving grounds of the American Southwest, such as the Nevada Test and Trinity Sites, as well as ongoing uranium mining in the Navajo Nation, producing a "national sacrifice zone" in the country's interior.

4 The Marshall Islands had previously been under successive colonization by Spain, Germany, and Japan.

5 The geographies of the Marshalls are worth noting here, in that island and atoll resources varied enormously and thus shaped the historic location of communities and settlements. This significantly impacted the survivability for ri-Pikinni at their successive relocations, producing conditions of starvation exacerbated by abandonment by the United States and its failure to supply food or water rations. For a sobering account of this state-sponsored violence, see Martha Smith-Norris's section on “Nuclear Nomads” (2017, 44-53).
} 
"No one quite knows what will happen to Bikini after the bomb is dropped, except that there will be very little left on it" (Life 1946, 105). Photographs anchoring this text portrayed islanders bidding their ancestors' graves goodbye, hauling material possessions down the beach to an awaiting American warship, and, finally, cheerfully waving handkerchiefs as they shoved off from the shores of their homeland. Buried under the more prominent photographs of Operation Crossroads that mark this historical moment-spectacular explosions with seawater erupting in plumes around nuclear mushroom clouds, surrounded by ghost ships and sacrificed islands bearing witness-these images produced narratives of Indigenous relocation as a matter of colonial benevolence, with opportunities to begin anew as they sacrificed their present worlds for white futures (Pitkanen and Farish 2018, 868; Atkinson 2011). ${ }^{6}$

Less acknowledged than the Marshall Islands, but equally relevant to the placebased contexts of Rise, is the role that Greenland was made to play in Cold War politics by colonial powers unconcerned with effects on Inuktun and their territories. Just as Marshallese were displaced from Pikinni and other atolls, Inuktun were moved to accommodate American military operations. One of several permitted defense areas for American military forces through the Defense of Greenland Agreement of 1951 under NATO, Thule Air Base began as an air station that quickly expanded to a full military base (Petersen 2008, 76). One of the largest military bases ever constructed by the United States, Thule served as a key strategic location for anti-Soviet defense and, simultaneously, distracted from undisclosed nuclear activity at nearby Camp Century, a "city under the ice" that housed an arsenal of six hundred nuclear missiles within striking distance of the Soviet Union. The lands upon which these projects developed are the traditional hunting grounds for the northeastern Indigenous settlements of Uummannaq and Pituffik, and so plans for Thule's expansion in May 1953 included the forced removal of eighty-seven Inuktun and the demolition of their homes (Brown 2002; Leonard 2010; Johansen 2008; Ngiviu 2014). The Inuktun were first brought to temporary housing and, next, to hastily constructed housing developments in Qaanaaq; the Danish government would go on to characterize Inuktun relocation as voluntary (Kristensen and Christensen 2009; Nielsen 2017).

Because the removal of Indigenous communities rendered places like Pikinni and Pituffik empty and thus available for nuclear projects, it bears lingering on the (presumed willing) mobilities that preconditioned these productions of terra nullius (Maclellan 2005, 363). ${ }^{7}$ As Keith Parsons and Robert Zaballa discuss in their book on the bombing of the Marshall Islands, the US military took pains to portray the Marshallese as "carefree," "grateful," and "nomadic"

\footnotetext{
6 Laura Pitkanen and Matthew Farish report that these detonations were heavily documented and photographed, with "'scores of professional cameramen,' who recorded '1,500,000 feet of film and over 1 million pictures”' $(2018,868)$.

7 As Maclellan writes in his article describing Pacific Islander responses to nuclearization, "a central feature of planning for nuclear testing was a casual racism toward the indigenous inhabitants of the region” $(2005,363)$.
} 
(2017, 14-15). Likewise, the Danish government framed Inuktun as both willing to move and itinerant by nature; they have since struggled to gain legal recognition as Indigenous peoples and, in turn, to assert their claims to Thule (Lynge 2002). These discourses importantly resonate with nineteenth-century Indian removal policies on the American continent, which imagined manifest destinies that denied the presence of and simultaneously targeted so-called nomadic peoples in the name of Lockean logics of (white) possession, in which the right to territory emerges through labor (Nichols 2018; Deloria 1988; Day 2015). ${ }^{8}$

\section{Imperial Domesticities}

Understanding settler colonial power through the lens of pervasive violence-subterranean embeddedness, atmospheric toxicity-in turn reveals the heightened dynamics of visibility and invisibility within visual representations of the nuclear. The media campaigns surrounding nuclear testing in the Pacific and the construction of Camp Century in Greenland exemplify strategic propagandizing of American imperial power through domestic space. Media produced about Kuwajleen Atoll in the Marshall Islands and Camp Century in Greenland importantly showcased the kinds of comforting supports installed for American military personnel at the front lines of testing and defense. Through photo essays like those published in Life and newsreels promoted by the US Department of Defense, popular media offered visions of US military bases as bastions of domesticity. The claims to power and space that underpinned nuclear programs in the Marshalls and Greenland required domestic components and, once emptied of their original inhabitants, offered blank slates for replicating and affirming American ideals through the built environment. So, as the threat of nuclear annihilation pressed upon American imaginations across the 1950s and '60s, a resolute embrace of nuclear-family values offered a sense of stability both at home and abroad. Here I track the promissory fantasies of American domesticity as they were projected outward to US Cold War military installations: the homes away from homes that sustained atomic violence in the shadows of empire.

In her landmark article, "bikini and other s/pacific n/oceans," Teresia Teaiwa unspools the ideological links between Pacific nuclear testing and concurrent investments in the masculinized and heterosexual gaze facilitated by the bikini swimsuit. "The sacrifice of Islanders and military personnel during nuclear testing in the Pacific," she writes, "cannot be represented without threatening the legitimacy of colonial power, so nuclear technology becomes gendered and domesticated" (Teaiwa 1994, 92). Teaiwa's deployment of the garment as a sexualizing idiom that obscures ri-Pikinni traumas importantly signals how gendered proscriptions are likewise embedded in normative domestic roles

\footnotetext{
8 Important theorization has been done through Indigenous and Black studies to understand how complexly these logics worked toward genocide and dispossession through racial capitalism.
} 
epitomized by the American nuclear family. This atomic "unit" remains one of the most indelible social artifacts of the Cold War, with its normative imaginaries continuing to reverberate across our contemporary legal and political landscape. In the wake of the Second World War, these spatial and cultural logics of containment and separation took shape against soldiers returning home to government-backed mortgages that realized single-family homeownership, spikes in marriage and birth rates, decreased divorce rates, and increased household spending. Historian Stephanie Coontz argues that not only was the nuclear family a "new invention" of the midcentury, but its expression was hermetic: "a whole world of satisfaction, amusement, and inventiveness” would be contained within (Coontz 1992, 27). So, as Elaine Tyler May suggests in her landmark work on American Cold War domesticity, while suburban middle-class aspirations were not limited to the white middle class, American media illustrated these value systems as such, thereby implicitly and explicitly linking ideas of safety to whiteness, private property, and gender normativity (May [1988] 2008).

These ideologies were exported in the form of US military installations like the US Army Garrison Kwajalein Atoll and Greenland's Camp Century, constructed in midcentury. Claimed from Japanese occupation in 1944, Kuwajleen became the staging ground for Operation Crossroads in 1946 and then expanded in the 1960s as a strategic site for missile development in the Marshall Islands. Historian Lauren Hirschberg's analysis of the suburbanization of Kuwajleen highlights how the heteronormative nuclear family structure became central to the remaking of the atoll as both a space of exception and "a colonial technology for marking the island as a familiar domestic national space” (Hirschberg 2011, 17; Gillem 2007). Through a major partnership with Bell Telephone Laboratories, the US military promoted life on Kuwajleen as a space of supreme comfort and leisure through the publication of welcome guides that boasted salons, prime rib dinners, and department store shopping (Hirschberg 2011, 234; Hirshberg 2012, 41).' Meanwhile, Marshallese day laborers who provided janitorial, housekeeping, and groundskeeping services commuted from Epjā (Ebeye), where they lived both segregated from and economically beholden to the base; these spatial and economic arrangements continue today.

Newsreels about Camp Century similarly highlighted features designed to replicate American suburban life "under the ice." Created by the United States in 1960, Camp Century operated as a cover for Project Iceworm, which used a network of subterranean tunnels burrowed under the Greenland ice sheet as a nuclear arsenal. The camp, which operated only until 1966, comprised living quarters, research facilities, and a portable nuclear reactor for the stated purpose of better understanding military effectiveness and operations in Arctic 
conditions. In the minds of Americans, who came to know this "city under the ice" through maps, photographs, and live footage circulated by the US government, it functioned as a kind of ultimate fantasy fallout shelter that promised to keep the American way of life secure and safe (Nielsen, Nielsen, and Martin-Nielsen 2014, 448; Masco 2009; Hollar-Zwick 2013). The US Department of Defense 1961 short film Big Picture: City under the Ice is one example of the substantial media production surrounding Camp Century, which reveled in the engineering used to build closed-system facilities for maintaining American lifestyles amid what is frequently referred to as "barren" and "lifeless" landscapes. In it, the narrator lists items representing domestic comforts: prefabricated houses, hot showers, and "even ice cream" as a subtle underscore of the hermetic barrier between the bunker and the glacier (United States Army Signal Corps Pictorial Service 1961). These "national security spaces" thereby reinforced the racial, class, and gender ideologies that marked postwar America, which reacted to the slow erosion of unwaged women's domestic work, Black economic upward mobility, and nuclear precarity with spatial commitments to boundaries and containment (Lichtman 2006; Vesentini 2015; Masco 2009).

\section{Infrastructural Instability and Lessons in Permanence}

The development of perinuclear space as a project of American dis/possession required, then, a number of infrastructural investments-material and social-to embed US power in these landscapes. The military bases of Thule and Kwajalein today remain robust through ongoing infusions of capital and a desire to maintain a sense of national security through what sociologist David Vine has called a vast network of "lily pad" bases (Vine 2015; Immerwahr 2019). Identifying nuclear power as a metaphorical and technological apparatus of American empire signals important connections between the "structures" of colonialism and the infrastructures of energy that comprise its material substrata. As Anne Spice points out in their analysis of Indigenous resistence to oil pipelines as "critical infrastructures" of the settler state, longstanding "binaries of civilized/savage and culture/nature" continue to inform theorizations of the built environment as marks of modernity. The role that infrastructure plays in state-building projects has a capillary function, pumping power in the form of oil, electricity, water, people, and capital into Indigenous territories in ways that, in turn, obscure Native presence. Tracing a substantial anthropology of infrastructure that locates transportation systems like pipelines, railroads, and highways as "settler colonial technologies of invasion," Spice reveals how these material networks naturalize settler presence as seemingly stable, inevitable, and permanent (Spice 2018, 45). As Brian Larkin furthermore remarks, these infrastructures appear stable or permanent only to those they are designed to serve, arguing that "the ambient conditions of everyday life" that they produce result in vastly differentiated experiences 
(Larkin 2013, 336). We might consider, for example, how the comforts of Kuwajleen are not extended to domestic workers commuting daily from nearby Epjā.

As an affront to the facades of stability maintained by the bases themselves, the infrastructures built to contain nuclear contamination have been revealed as fragile. The Runit Dome, visually referenced in Rise, was completed between 1977 and 1980 on Runit Island in Ānewetak (Enewetak) Atoll. It is a concrete tomb that holds over 104,000 cubic yards of contaminated debris produced by the sixty-seven nuclear tests across the midcentury. It fills in a crater left by the Cactus Test, which resulted in the detonation of a bomb roughly the size of that dropped on Hiroshima (Gerrard 2015). Runit Dome holds some, though not all, of the radioactive debris left over from these tests (including plutonium-239, with a half-life of twenty-four thousand years), which the United States collected and bulldozed into the Cactus Test crater as part of an $\$ 86.7$ million cleanup in anticipation of granting independence to the Marshall Islands in the 1970s. The United States selected the Runit site despite the fact that "the crater was below sea level at high tide, that the coral rock was naturally permeable, and that there had been three other nuclear detonations within three hundred feet, so that the rock was highly fractured" (Gerrard 2015, 88). Cost-cutting measures during the dome's construction reveal the contours of the RMI sacrifice zone (Lerner 2012): the United States employed soldiers at half the pay of nuclear specialists to clean up on Ānewetak, failing to issue protective gear and later denying medical coverage for the cancers they would develop (Willacy 2017); the architects of the dome furthermore did not account for anthropogenic changes to the environment, including sea level rise and extreme weather events, like typhoons, that may lead to the "catastrophic failure" of the structure (Gerrard 2015, 93). ${ }^{10}$ The recent discovery of radioactive giant clams in the surrounding sea offers vibrant evidence that the dome is leaking radiation into the Pacific.

The instability of Camp Century revealed itself much earlier-only six years after its construction. The US Army selected the camp's location based upon assumptions that the ice offered a stable and resilient shield against retaliatory strikes "far from populated areas while remaining within range of enemy targets" (Weiss 2001, 43). In reality, the material conditions of Greenland's ice shelf proved prohibitively dynamic for the camp and the missile tunnels that it obscured, and so the entire facility was abandoned in 1966, not six years after its completion. Despite the reasons for abandonment, assumptions about glacial stability guided the decision to only minimally decommission the structures of the camp (Colgan et al. 2016, 8091). Today glacial melts-occurring in significant excess of projected rates-have the potential

\footnotetext{
10 I am grateful to the anonymous reviewer who noted that the radiological impacts of Operation Crossroads were, of course, not limited to Marshallese, drawing attention to the settler state's readiness to sacrifice citizens both Indigenous and non-Native, including low-income servicemen.
} 
to remobilize the wastes of wartime nuclear projects as well as questions of accountability (Lunau 2018). Investigations into the hazardous future of Cold War defense outposts embedded within Greenland's landscape lack clarity regarding the treaty terms under which they were established. Not only do they offer unclear directives about which nation is responsible for contaminants leeching from the now-abandoned structures, but they also fail to address the structural conditions by which Inuktun territory has been exploited in the service of colonial powers that understand its space to be empty, static, and available for use as a waste repository (Colgan et al. 2016, 8091).

\section{Indigenous Kinships as Resistance}

Commissioned by international climate justice advocacy group 350, Rise navigates these metaphorical and material waters by decentering the Western subjectivities and futures proposed by crumbling infrastructures of power. Instead, the poem articulates Greenland and the Marshall Islands relative to each other and thus as interdependent partners in global environmental justice: a form of kinship illustrated through the dialogues of Jetñil-Kijiner and Niviâna as Indigenous climate change activists deeply invested in colonial critique (Faris 2019, 77). ${ }^{11}$ Set along the shorelines of the Marshall Islands and the stark ice sheets of Greenland, Jetñil-Kijiner and Niviâna's film trains our eyes on water as a common, elemental component of life as it shape-shifts across the globe between liquid, vapor, and solid. Nearly every shot of the sixand-a-half-minute video is saturated in grays, whites, and blues that underscore the aqueous connections between the film's two locations. Its visual composition pulls these seemingly diametric places into the same analytic frame-not as juxtaposition but instead as spaces of affinity: much of Greenland is glacial, just as much of the Marshalls is ocean, and so their territories are rendered dynamic by the same ebbs and flows.

This articulation of Indigenous embodiments through elemental frameworks constitutes what Jaime Hamilton Faris terms a hydro-ontology: an aquapelagic orientation that serves to unsettle terrestrial relationships to place (Faris 2019, 79). To live in and with water, then, is to be sharply aware of its power to change form, direction, and benevolence. David Macauley explains in his book Elemental Philosophy that for Western thinkers, water has always provoked a kind of anxiety over its resistance to control (Macauley 2010, 48). Such a perspective, however, images man as a dominant actor within that relationship. Niviâna explains, to the contrary:

This is a story about

the guardian of the Sea.

11 For more on Jetñil-Kijiner's anti-nuclear poetry and activism, see work by Michelle Keown, particularly her 2019 article, "Waves of Destruction: Nuclear Imperialism and anti-nuclear protest in the indigenous literatures of the Pacific.” 


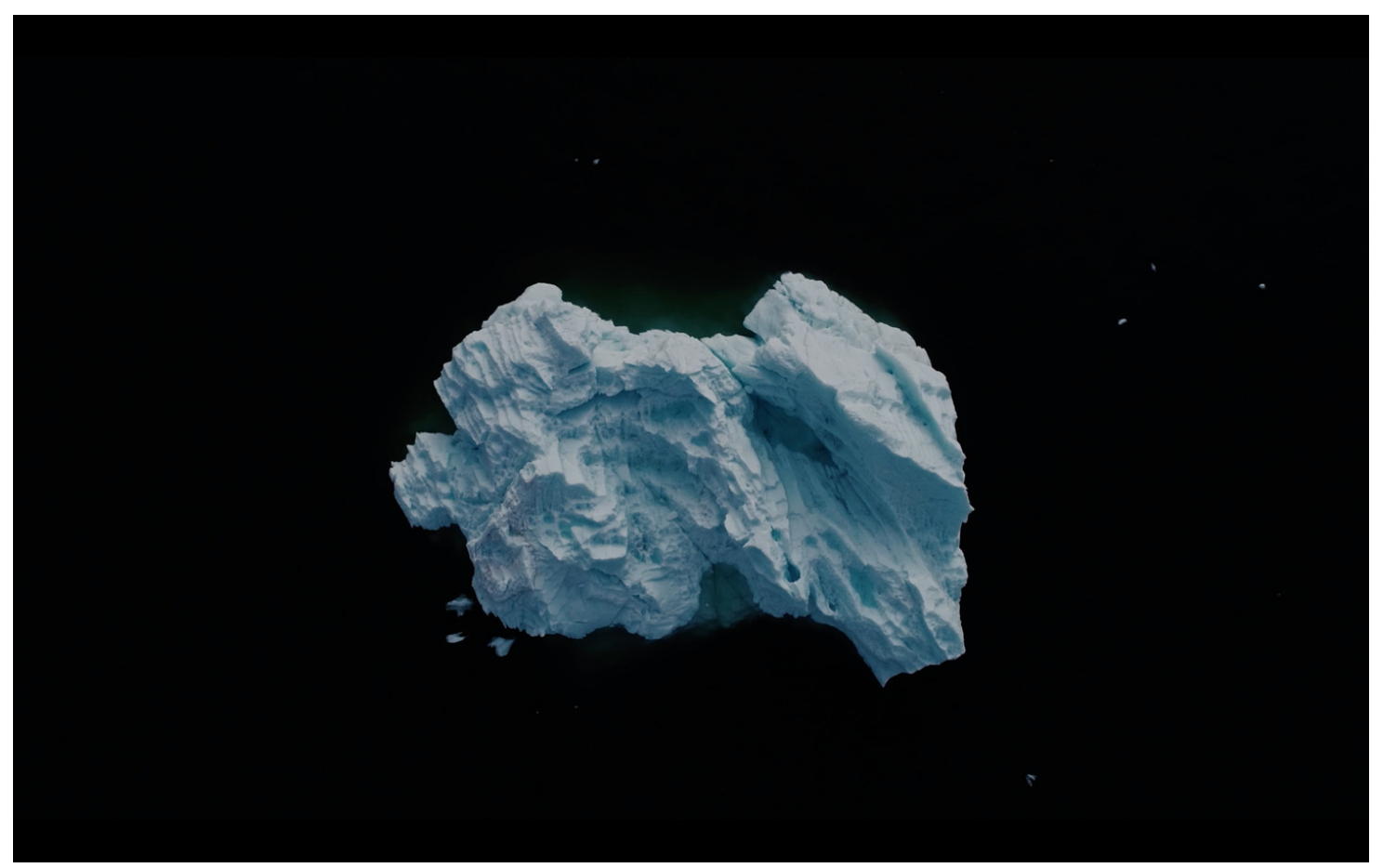

Figure 2: Rise: From One Island to Another.

Source: Image courtesy of the artists.

She sees the greed in our hearts,

the disrespect in our eyes.

Every whale, every stream,

every iceberg

are her children.

When we disrespect them

she gives us what we deserve,

a lesson in respect.

In posing questions about culpability and authority, Niviâna calls upon her audience to acknowledge the relations between oceanscapes and islanders that the Western world has long treated as inconsequential. "Do we deserve the melting ice?” she asks the reader, before pleading for solutions.

By drawing on nuclear histories to talk about climate change in the present and the future, Rise highlights how themes of toxicity and displacement bookend what it means to be a contemporary Marshallese or Inuk. "I come to you now in grief," recites Jetñil-Kijiner: 
mourning landscapes

that are always forced to change

first through wars inflicted on us

then nuclear waste

dumped

in our waters

on our ice

and now this.

Indigenous territories sacrificed as the staging grounds for Cold War nuclear activity depended on presumptions of terra nullius, or at least a terra that could be easily made nullius by removing the people who lived there. JetñilKijiner and Niviâna's accounting of First-World commitments to fossil fuels and "SUV's, ac's, [and] pre-packaged convenience" reckons with how those systems operate on the oppression of others, particularly Indigenous communities whose homelands have been used and discarded by consumerist practices in conjunction with wartime maneuvering. Once emptied and their future habitability compromised, they have been left inadequately remediated and their peoples doubly (and permanently) displaced (Leahy 2019; Davenport 2015).

As a refusal of victimhood, the video builds and then culminates as JetñilKijiner and Niviâna's voices harden, the music intensifies, and the poets face each other atop a glacier with gifts of shell and stone. They make their offerings with vows of resilience, stating, "may the same unshakable foundation connect us... as a testament, as a declaration, that despite everything, we will not leave." Surrounded by the forced alienation of island and sea, these gifts reflect resolve in oceans of uncertainty. Jetñil-Kijiner explains in a supplemental essay entitled "The Process of the Poem" that stone offered a sense of permanence she felt important to convey. Inspiration came, in part, from a Marshallese legend of two sisters who engaged in a juggling competition around the island of Ujae. When one of the sisters drops the rock she is juggling, she turns to stone. The other then drops her rock, too, and chooses to turn to stone with her sister. "The moral of the story," Jetñil-Kijiner explains, "is the love that connected the two sisters" (Jetñil-Kijiner 2019). This (hi)story is implicitly referenced within Rise, through images of the Sassuma Arnaa (Mother of the Sea) statue in Nuuk harbor, Niviâna's gift of stones nestled like eggs in gleaming ice, and Jetñil-Kijiner's shells tucked into a delicately woven basket. These exchanges underscore the interdependence that humans have with the nonhuman world 


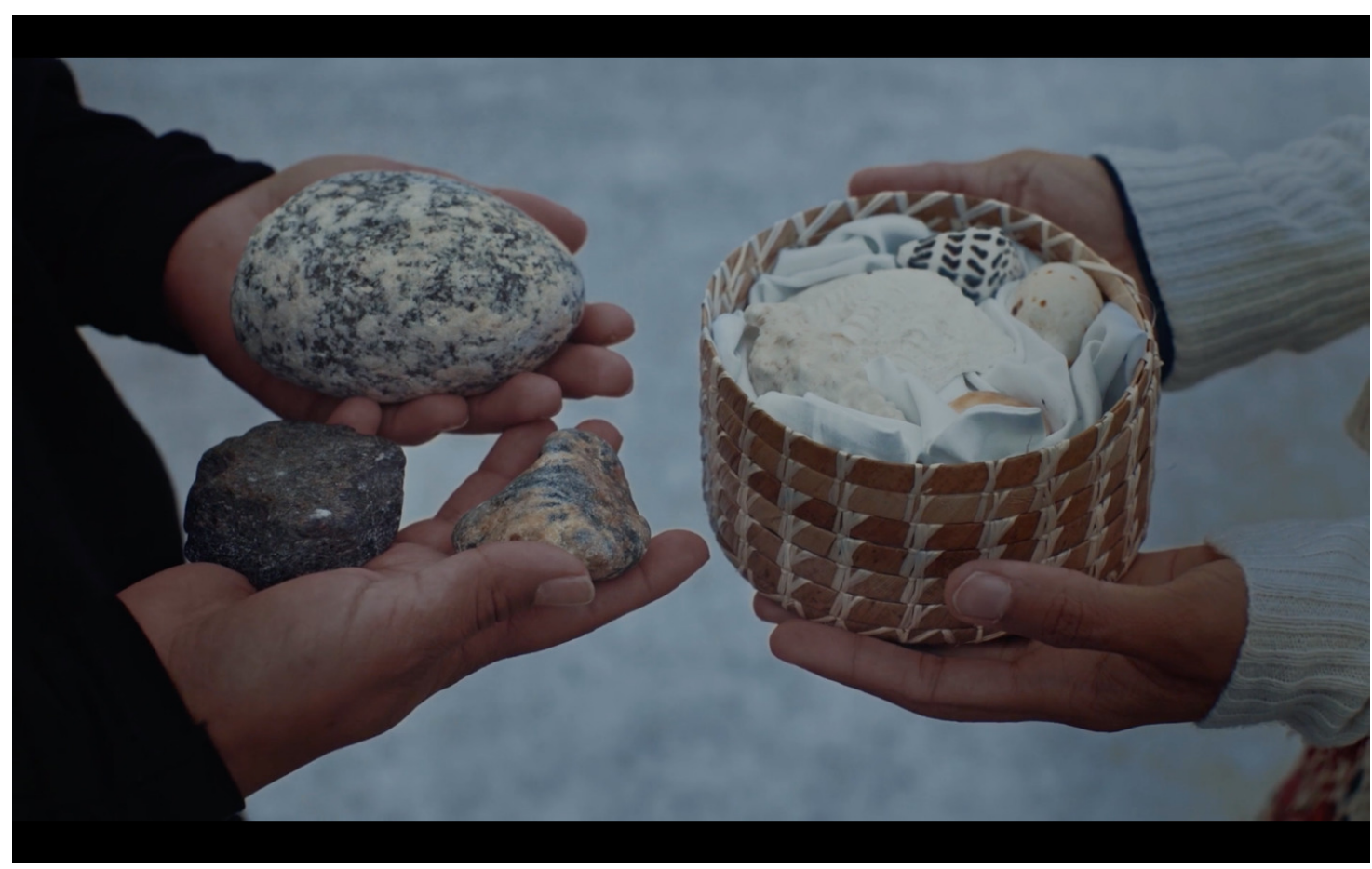

Figure 3: Rise: From One Island to Another.

Source: Image courtesy of the artists.

(Phillips 2016; Alaimo 2008). ${ }^{12}$ To take this concept further, Rise grounds Indigenous activism and poetics in place-based epistemologies and ontologies that bind together environment, deep time, and relationality: expansive and elemental ways of being in the world that exceed units of atoms or the purported smallness of islands (Hau'ofa 1994; Fujikane 2020).

This crescendo offers a particularly salient response to the heteronormative infrastructures so violently imposed upon their territories. Instead of the faulty boundaries and fragile containments of the nuclear age, the relationship between Jetñil-Kijiner and Niviâna is expansive, crossing space, time, and form (Haraway 2015). Because water offers imaginative possibilities not typically afforded to land, in that land is often considered stable in opposition to the fluidity of water, Rise thus troubles the boundaries between them. In doing so, the film highlights how these islands are constituted by water, rather than simply surrounded by it. As Vicente Diaz reminds us through his analysis of Carolinian seafaring ontologies, "islands are a product of continental and imperialist thinking," which can produce false categories of opposition between water and land (Diaz 2015, 101). Part of the danger in this thinking is the assumption that islands offer materially stable repositories for the refuse of military imperialism. The concrete permanence suggested by the materials of stone and shell (as opposed to ice or sand) thereby extends beyond references 
to more Western notions of terra or territory, and toward an acknowledgment of the kinds of resiliency that can be forged through trans-Indigenous kinship. Such gifts are necessary for building awareness, in the words of these two poets, of "how large, and yet so small and interdependent our world is." Through its subtle but persistent evocation of atoms and elements, $R$ ise takes the seemingly insignificant and makes it gigantic. In doing so, it holds the viewer accountable to the ways in which islands and islanders have been historically overlooked as small or unimportant at the same time that they make visible our shared planetary fate. "Let me bring my home to yours," they offer. "You think you have decades before your homes fall beneath tides? We have years. We have months.”

Artistic productions like Rise importantly recontextualize Cold War events of the past as an ongoing disaster of the present-one that constrains a collective, planetary future. Even as Jetñil-Kijiner and Niviâna appeal to a sense of precarity for all, they hold focus on the lived realities of Inuktun and Marshallese, carefully juxtaposing a "we" and a "you" that refuses to collapse specific experiences and realities of climate change. As the editors of this thematic stream argue, such attendance to the porous boundaries of "disaster" offers opportunity to think about the forms of allyship that might emerge from increased historical and political consciousness. Most cogently, the example of Rise brings attention to how geopolitical power shapes relationships with the environment. Here, a trans-Indigenous sisterhood proposes an expansive corrective to the fictions of containment posed by the nuclear heteropatriarchies of the Cold War. For the Western subjects to whom Rise is addressed, then, relationality in and of itself becomes both a method and a practice for an environmentally just future that goes beyond land, beyond humans, and beyond containment. 


\section{REFERENCES}

Alaimo, Stacy. 2008. “Trans-Corporeal Feminisms and the Ethical Space of Nature.” In Material Feminisms, edited by Stacy Alaimo and Susan J. Hekman. Bloomington: Indiana University Press. Atkinson, Nathan S. 2011. "Newsreels as Domestic Propaganda: Visual Rhetoric at the Dawn of the Cold War.” Rhetoric छ? Public Affairs 14 (1): 69-100. https://doi.org/10.1353/rap.2011.0003.

Bahng, Aimee. 2020. "The Pacific Proving Grounds and the Proliferation of Settler Environmentalism.” Journal of Transnational American Studies 11 (2): 45-73.

Brown, DeNeen L. 2002. “Trail of Frozen Tears.” Washington Post, October 22, 2002.

Colgan, William, Horst Machguth, Mike MacFerrin, Jeff D. Colgan, Dirk van As, and Joseph A. MacGregor. 2016. "The Abandoned Ice Sheet Base at Camp Century, Greenland, in a Warming Climate.” Geophysical Research Letters 43 (15): 8091-96. https://doi.org/10.1002/2016gl069688.

Coontz, Stephanie. 1992. The Way We Never Were: American Families and the Nostalgia Trap. New York: Basic Books.

Davenport, Coral. 2015. "The Marshall Islands Are Disappearing.” The New York Times, December 2, 2015. https://www.nytimes.com/interactive/2015/12/02/world/The-Marshall-Islands-AreDisappearing.html.

Davis, Heather, and Zoe Todd. 2017. "On the Importance of a Date, or Decolonizing the Anthropocene.” ACME 16 (4): 761-80.

Day, Iyko. 2015. "Being or Nothingness: Indigeneity, Antiblackness, and Settler Colonial Critique." Critical Ethnic Studies 1 (2): 102-21.

Deloria, Vine, Jr. 1988. Custer Died for Your Sins: An Indian Manifesto. Norman: University of Oklahoma Press.

Diaz, Vicente. 2015. "No Island Is an Island.” In Native Studies Keywords, edited by Stephanie Nohelani Teves, Andrea Smith, and Michelle Raheja. Tucson: University of Arizona Press.

Farbotko, Carol. 2010. "Wishful Sinking: Disappearing Islands, Climate Refugees and Cosmopolitan Experimentation." Asia Pacific Viewpoint 51 (1): 47-60. https://doi.org/10.1111/ j.1467-8373.2010.001413.x.

Faris, Jaimey Hamilton. 2019. "Sisters of Ocean and Ice: On the Hydro-Feminism of Kathy JetñilKijiner and Aka Niviâna’s Rise: From One Island to Another.” Shima 13: 76-99.

Fujikane, Candace. 2020. Mapping Abundance for a Planetary Future. Durham, NC: Duke University Press. https://doi.org/10.1515/9781478021247.

Gerrard, Michael B. 2015. "America’s Forgotten Nuclear Waste Dump in the Pacific.” SAIS Review of International Affairs 35 (1): 87-97. https://doi.org/10.1353/sais.2015.0013.

Gillem, Mark L. 2007. American Town: Building the Outposts of Empire. Minneapolis: University of Minnesota Press.

Hales, Peter B. 1991. “The Atomic Sublime.” American Studies 32 (1): 5-31.

Haraway, Donna. 2015. "Anthropocene, Capitalocene, Plantationocene, Chthulucene: Making Kin.” Environmental Humanities 6 (1): 159-65. https://doi.org/10.1215/22011919-3615934.

Hau'ofa, Epeli. 1994. “Our Sea of Islands.” The Contemporary Pacific 6 (1): 147-61.

Hirschberg, Lauren B. 2011. "Targeting Kwajalein: US Empire, Militarization and Suburbanization, and the Marshall Islands, 1944-1986.” PhD diss., University of Michigan.

Hirshberg, Lauren B. 2012. "Nuclear Families: (Re)Producing 1950s Suburban America in the Marshall Islands." OAH Magazine of History 26 (4): 39-43. https://doi.org/10.1093/oahmag/ oas 034 . 
Hobart, Hi ilei Julia. 2020. “On Oceanic Fugitivity.” Items (blog). September 9, 2020.

https://items.ssrc.org/ways-of-water/on-oceanic-fugitivity/.

Hogue, Rebecca, and Anaïs Maurer. 2020. "Special Forum Introduction: Transnational Nuclear Imperialisms.” Journal of Transnational American Studies 11 (2): 25-43.

Hollar-Zwick, Carol M. 2013. "Persuaded to Prepare: Rhetoric and a Cold War Fallout Shelter." MA Thesis, Oshkosh: University of Wisconsin.

Immerwahr, Daniel. 2019. How to Hide an Empire: A History of the Greater United States. New York: Picador.

Jetñil-Kijiner, Kathy. 2019. “The Process of the Poem: Selecting the Legend.” In Rise: From One Island to Another. https://350.org/rise-from-one-island-to-another/.

Jetñil-Kijiner, Kathy, and Aka Niviâna. 2019. Rise: From One Island to Another. https://350.org/risefrom-one-island-to-another.

Johansen, Pia Krüger. 2008. “Thule.” In A Historical Companion to Postcolonial Literatures: Continental Europe and Its Empires, edited by Prem Poddar and Rajeev Patke. Edinburgh: Edinburgh University Press.

Keju-Johnson, Darlene. 2003. “For the Good of Mankind.” Seattle Journal for Social Justice 2 (1): 309-14.

Keown, Michelle. 2019. "Waves of Destruction: Nuclear Imperialism and Anti-Nuclear Protest in the Indigenous Literatures of the Pacific.” Journal of Postcolonial Writing 54 (5): 585-600.

Kirsch, Scott. 1997. "Watching the Bombs Go Off: Photography, Nuclear Landscapes, and Spectator Democracy." Antipode 29 (3): 227-55. https://doi.org/10.1111/1467-8330.00045.

Kristensen, Kristian Søby, and Svend Aage Christensen. 2009. "Greenlanders Displaced by the Cold War: Relocation and Compensation.” In Historical Justice in International Perspective: How Societies Are Trying to Right the Wrongs of the Past, edited by Manfred Berg and Bernd Schaefer. Cambridge: Cambridge University Press.

Larkin, Brian. 2013. "The Politics and Poetics of Infrastructure.” Annual Review of Anthropology 42 (1): 327-43. https://doi.org/10.1146/annurev-anthro-092412-155522.

Leahy, Stephen. 2019. “Greenland's Ice Is Melting Four Times Faster than We Thought - What It Means.” National Geographic, January 21, 2019. https://www.nationalgeographic.com/ environment/2019/01/greeland-ice-melting-four-times-faster-than-thought-raising-sea-level/.

Lempert, William. 2018. "Generative Hope in the Postapocalyptic Present." Cultural Anthropology 33 (2): 202-12. https://doi.org/10.14506/ca33.2.04.

Leonard, Stephen Pax. 2010. “The Disappearing World of the Last of the Arctic Hunters." The Observer, October 2, 2010. https://www.theguardian.com/world/2010/oct/03/last-of-the-arctichunters.

Lerner, Steve. 2012. Sacrifice Zones: The Front Lines of Toxic Chemical Exposure in the United States. Cambridge, MA: MIT Press.

Lichtman, Sarah A. 2006. "Do-It-Yourself Security: Safety, Gender, and the Home Fallout Shelter in Cold War America." Journal of Design History 19 (1): 39-55. https://doi.org/10.1093/jdh/epk004.

Life. 1946. "Atom Bomb Island: Navy Moves Natives from Bikini, Target of Operation Crossroads," March 25, 1946.

Lunau, Kate. 2018. “A Top-Secret Military Base Will Melt Out of the Greenland Ice Sheet.” Vice, February 20, 2018. https://www.vice.com/en_us/article/d3wdb7/cold-war-era-nuclear-base-campcentury-melting-climate-change-greenland.

Lynge, Aqqaluk. 2002. The Right to Return: Fifty Years of Struggle by Relocated Inughuit in Greenland. Nuuk, Greenland: Forlaget Atuagkat. 
Macauley, David. 2010. Elemental Philosophy: Earth, Air, Fire, and Water as Environmental Ideas. Albany: State University of New York Press.

Maclellan, Nic. 2005. "The Nuclear Age in the Pacific Islands." The Contemporary Pacific 17 (2): 363-72. https://doi.org/10.1353/cp.2005.0062.

Masco, Joseph. 2006. The Nuclear Borderlands: The Manhattan Project in Post-Cold War New Mexico. Princeton, NJ: Princeton University Press. https://doi.org/10.1515/9781400849680.

- - 2009. "Life Underground: Building the Bunker Society." Anthropology Now 1 (2): 13-29.

May, Elaine Tyler. (1988) 2008. Homeward Bound: American Families in the Cold War Era. New York: Basic Books.

Ngiviu, Terto. 2014. "The Inughuit of Northwest Greenland: An Unacknowledged Indigenous People." The Yearbook of Polar Law Online 6 (1): 142-61. https://doi.org/10.1163/ 1876-8814_006.

Nichols, Robert. 2018. "Theft Is Property! The Recursive Logic of Dispossession.” Political Theory 46 (1): 3-28. https://doi.org/10.1177/0090591717701709.

Niedenthal, Jack. 1997. "A History of the People of Bikini Following Nuclear Weapons Testing in the Marshall Islands: With Recollections and Views of Elders of Bikini Atoll." Health Physics 73 (1): 28-36. https://doi.org/10.1097/00004032-199707000-00003.

Nielsen, Kristian Hvidtfelt. 2017. "Camp Century's Degrees of Coldness: From Cold War Icon to Climate Change-Induced Problem.” Nach Feierabend. Zürcher Jabrbuch für Wissensgeschichte 13: $17-37$.

Nielsen, Kristian Hvidtfelt, Henry Nielsen, and Janet Martin-Nielsen. 2014. "City under the Ice: The Closed World of Camp Century in Cold War Culture.” Science as Culture 23 (4): 443-64. https://doi.org/10.1080/09505431.2014.884063.

Parsons, Keith M., and Robert A. Zaballa. 2017. Bombing the Marshall Islands: A Cold War Tragedy. Cambridge: Cambridge University Press. https://doi.org/10.1017/9781107239036.

Petersen, Nikolaj. 2008. "The Ice Man That Never Came: 'Project Iceworm,' the Search for a NATO Deterrent, and Denmark, 1960-1962.” Scandinavian Journal of History 33 (1): 75-98. https://doi.org/10.1080/03468750701449554.

Phillips, Mary. 2016. “Developing Ecofeminist Corporeality: Writing the Body as Activist Poets.” In Contemporary Perspectives in Ecofeminism, edited by Mary Phillips and Nick Rumens, 57-75. London: Routledge.

Pitkanen, Laura, and Matthew Farish. 2018. "Nuclear Landscapes." Progress in Human Geography 42 (6): 862-80. https://doi.org/10.1177/0309132517725808.

Powell, Dana E. 2018. Landscapes of Power: Politics of Energy in the Navajo Nation. Durham, NC: Duke University Press. https://doi.org/10.1215/9780822372295.

Simmons, Kristen. 2017. "Settler Atmospherics.” Member Voices, Fieldsights, November 20, 2017. https://culanth.org/fieldsights/settler-atmospherics.

Smith-Norris, Martha. 2017. Domination and Resistance: The United States and the Marshall Islands During the Cold War. Honolulu: University of Hawai'i Press. https://doi.org/10.21313/hawaii/ 9780824847623.001 .0001$.

Spice, Anne. 2018. “Fighting Invasive Structures: Indigenous Relations Against Pipelines.” Environment and Society 9 (1): 40-56.

Suliman, Samid et al. 2019. "Indigenous (Im)Mobilities in the Anthropocene.” In Mobilities, 1-21.

TallBear, Kim. 2017. "Beyond the Life/Not Life Binary: A Feminist-Indigenous Reading of Cryopreservation, Interspecies Thinking and New Materialism.” In Cryopolitics: Frozen Life in a Melting World, edited by Joanna Radin and Emma Kowal. Cambridge: MIT Press. 
Teaiwa, Teresia. 1994. "Bikinis and Other s/Pacific n/Oceans." The Contemporary Pacific 6 (1): 87-109.

United States Army Signal Corps Pictorial Service. 1961. The Big Picture's City under the Ice: Camp Century.

Vesentini, Andrea. 2015. "Sheltering Time: The Containment of Everyday Life in Nuclear-Shelter Film Narratives.” Material Culture 47 (2): 41-58.

Vine, David. 2015. Base Nation: How US Military Bases Abroad Harm America and the World. New York: Metropolitan Books.

Weiss, Erik D. 2001. "Cold War Under the Ice: The Army's Bid for a Long-Range Nuclear Role, 1959-1963.” Journal of Cold War Studies 3 (3): 31-58. https://doi.org/10.1162/ 152039701750419501.

Whyte, Kyle Powys. 2017. "Indigenous Climate Change Studies: Indigenizing Futures, Decolonizing the Anthropocene." English Language Notes 55 (1-2): 153-62. https://doi.org/10.1215/ $\underline{00138282-55.1-2.153 .}$.

Willacy, Mark. 2017. "It Was Supposed to Be a Trip to Paradise, Instead It Sealed Their Fate." $A B C$ News, November 28, 2017. https://www.abc.net.au/news/2017-11-28/the-toxic-legacy-of-adeadly-paradise/9168422?nw $=0$. 